\title{
PENGARUH PERHATIAN ORANG TUA DAN MOTIVASI BERPRESTASI TERHADAP PRESTASI BELAJAR PADA MATA PELAJARAN PEMELIHARAAN KELISTRIKAN KENDARAAN RINGAN KELAS XII DI SMKN 1 NGAWEN
}

\author{
Achmad Zunaidi \\ Jurusan Pendidikan Teknik Otomotif, Universitas Negeri Yogyakarta \\ Correspoding Author: achmad.zunaidi2016@student.uny.ac.id
}

\begin{abstract}
This study aims to: (1) determine the effect of parents attention on learning achievement; (2) Knowing the effect of achievement motivation on learning achievement; (3) Knowing the effect of parents attention and achievement motivation on the learning achievement of class XII student in the Light Vehicle Electrical Maintenance subject at SMK Negeri 1 Ngawen. The research carried out was ex post facto research. The place of this research is at SMK Negeri 1 Ngawen and the time of the research was conducted in the 2020/2021 academic year. The sample of this research is students of class XII TKR C in the subject of Light Vehicle Electrical Maintenance. The data collection technique is done by observation and questionnaires. The data used is quantitative data. The validity of the data was obtained through validity and reliability. The results of this study indicate that (1) Parents' attention have a significant effect on the Light Vehicle Electrical Maintenance Learning Achievement of Class XII TKR Students at SMK Negeri 1 Ngawen for the 2020/2021 academic year as seen from the value of tcount $=3.459$ with a significance value of 0.002, (2) Achievement motivation does not have a significant effect on the Learning Achievement of Electrical Light Vehicle Maintenance for Class XII TKR Students of SMK Negeri 1 Ngawen $2020 / 2021$ academic year which is seen from the value of tcount $=0.245$ with a significance value of 0.808 .
\end{abstract}

Keywords: parents attention, achievement motivation, learning achievement

\begin{abstract}
Abstrak
Penelitian ini bertujuan untuk: (1) Mengetahui pengaruh perhatian orang tua terhadap prestasi belajar; (2) Mengetahui pengaruh motivasi berprestasi terhadap prestasi belajar; (3) Mengetahui pengaruh perhatian orang tua dan motivasi berprestasi terhadap prestasi belajar siswa kelas XII mata pelajaran Pemeliharaan Kelistrikan Kendaraan Ringan di SMK Negeri 1 Ngawen. Penelitian yang dilaksanakan merupakan penelitian expost facto. Tempat penelitian ini di SMK Negeri 1 Ngawen dan waktu penelitian dilakukan pada tahun ajaran 2020/2021. Sample penelitian ini adalah siswa kelas XII TKR C pada mata pelajaran Pemeliharaan Kelistrikan Kendaraan Ringan. Teknik pengumpulan data dilakukan dengan observasi, dan kuisioner. Data yang digunakan merupakan data kuantitatif. Keabsahan data diperoleh melalui validitas dan reliabilitas. Hasil penelitian ini menunjukkan bahwa (1) Perhatian orang tua berpengaruh signifikan terhadap Prestasi Belajar Pemeliharaan Kelistrikan Kendaraan Ringan Peserta Didik Kelas XII TKR SMK Negeri 1 Ngawen Tahun Ajaran 2020/2021 yang dilihat dari nilai $t_{\text {hitung }}=3,459$ dengan nilai signifikansi sebesar 0,002, (2) motivasi berprestasi tidak berpengaruh signifikan terhadap Prestasi Belajar Pemeliharaan Kelistrikan Kendaraan Ringan Peserta Didik Kelas XII TKR SMK Negeri 1 Ngawen Tahun Ajaran 2020/2021 yang dilihat dari nilai $t_{\text {hitung }}=0,245$ dengan nilai signifikansi sebesar 0,808 .
\end{abstract}

Kata kunci: Perhatian Orang Tua, Motivasi Berprestasi, Prestasi Belajar 


\section{PENDAHULUAN}

Pendidikan adalah usaha manusia untuk mengembangkan potensi-potensi bawaan baik jasmani maupun rohani sesuai dengan nilai-nilai yang ada dalam masyarakat dan kebudayaan (Ikhsan, 2003:2). Tujuan pendidikan pada dasarnya menghantarkan para siswa menuju pada perubahan-perubahan tingkah laku baik intelektual, moral maupun sosial, agar dapat hidup mandiri sebagai individu dan makhluk sosial sehingga menghasilkan sumber daya manusia yang berkualitas. Sebagai bagian dari sistem pendidikan nasional, Pendidikan Menengah Kejuruan merupakan pendidikan yang mengutamakan keterampilan dan kemampuan siswa untuk mempersiapkan diri agar dapat bekerja dalam suatu bidang tertentu.

Berdasarkan hasil observasi yang telah dilakukan, terdapat 35 anak dari 115 anak atau 30,4\% yang belum bisa mencapai nilai 70 yang artinya masih di bawah Kriteria Ketuntasan Minimal (KKM). Hal ini membuktikan bahwa masih terdapat hambatan dalam pencapaian prestasi belajar peserta didik. Salah satu dari peranan orang tua terhadap keberhasilan pendidikan anaknya adalah dengan memberikan perhatian, terutama perhatian pada kegiatan belajar. Orang tua yang kurang/tidak memperhatikan pendidikan anaknya, misalnya acuh tak acuh terhadap beajar anaknya, tidak memperhatikan sama sekali akan kepentingan-kepentingan dan kebutuhan anaknya dalam belajar, tidak mengatur waktu belajarnya, tidak menyediakan/melengkapi alat belajarnya, tidak memperhatikan apakah anak belajar atau tidak, tidak mau tahu bagaimanakah kemajuan belajar anaknya, kesulitan-kesulitan yang dialami anak dalam belajar, dapat menyebabkan anak tidak/kurang berhasil dalam belajarnya. Perhatian merupakan suatu hal yang sangat penting diperlukan oleh anak karena perhatian orang tua memiliki pengaruh pada perkembangan anak.

Seorang siswa juga perlu diberikan rangsangan agar tumbuh motivasi dalam dirinya, agar seorang siswa mau melakukan pekerjan yang seharusnya dilakukan, yaitu belajar. Motivasi mengaktifkan dan mengarahkan perilaku seseorang untuk berkata, bertindak, dan melakukan sesuatu hal (Afifi \& Sukaswanto, 2020; Sjukur, 2012; Slavin, 2009). Rendahnya motivasi belajar terdapat dua sumber utama, yaitu berasal dari diri sendiri dan dari luar diri peserta didik. Motivasi dalam diri peserta didik bisa berupa gangguan otak, gangguan panca indra, cacat fisik dan gangguan psikis sedangkan motivasi dari luar peserta didik berupa keadaan keluarga, sarana dan prasarana sekolah, dan kondisi lingkungan masyarakat. Rendahnya motivasi yang diberikan oleh guru sangat berpengaruh pada peserta didik, sehingga peserta didik sering tidak memperhatikan ketika guru mata pelajaran sedang menjelaskan materi, kebanyakan peserta didik sibuk dengan kepentingannya sendiri. 
Berdasarkan beberapa uraian permasalahan di atas, peniliti bermaksud untuk melakukan sebuah penelitian yang berjudul "Pengaruh Perhatian Orang Tua Dan Motivasi Berprestasi Terhadap Prestasi Belajar Pada Mata Pelajaran Pemeliharaan Kelistrikan Kendaraan Ringan Kelas XII Di SMK N 1 Ngawen”.

Masalah yang diteliti pada penelitian ini adalah salah satu faktor internal yaitu motivasi dan salah satu faktor eksternal yang mempengaruhi keberhasilan belajar siswa yaitu perhatian orang tua pada siswa. Perhatian orang tua adalah kesadaran orang tua (ayah dan ibu) untuk memusatkan seluruh aktivitasnya yang ditujukan kepada anak-anaknya dalam bentuk kasih sayang dan kepedulian mereka yang tiada batas. Motivasi berprestasi adalah upaya menggerakkan atau memacu keinginan untuk meningkatkan prestasinya sehingga tercapai tujuan pendidikan sesuai dengan yang diharapkan yaitu memiliki kompetensi dibidangnya. Penelitian ini akan difokuskan pada hal-hal yang berkaitan dengan motivasi belajar dalam diri siswa dan hal-hal yang dibutuhkan anak untuk menunjang prestasi belajar anak yang diberikan oleh orang tua seperti memperhatikan kesehatan anak, pengawasan terhadap kegiatan belajar anak, penciptaan suasana belajar yang nyaman, pemenuhan kebutuhan belajar, memberikan bimbingan, serta memberikan penghargaan dan hukuman yang berpengaruh terhadap prestasi belajar kelistrikan otomotif. Prestasi belajar adalah penguasaan pengetahuan atau keterampilan yang dikembangkan oleh mata pelajaran, lazimnya ditunjukkan dengan nilai tes atau angka yang diberikan oleh guru. Dalam penelitian ini prestasi belajar yang digunakan adalah nilai Ujian Tengah Semester mata pelajaran PKKR pada tahun pelajaran 2020/2021.

Rumusan masalah yang diteliti pada penelitian ini adalah (1) Adakah pengaruh perhatian orang tua terhadap prestasi belajar pada mata pelajaran Pemeliharaan Kelistrikan Kendaraan Ringan kelas XII program keahlian Teknik Kendaraan Ringan SMK Negeri 1 Ngawen? (2) Adakah pengaruh motivasi berprestasi terhadap prestasi belajar pada mata pelajaran Pemeliharaan Kelistrikan Kendaraan Ringan kelas XII program keahlian Teknik Kendaraan Ringan SMK Negeri 1 Ngawen? Penelitian ini bertujuan untuk mengetahui Pengaruh perhatian orang tua dan pengaruh motivasi berprestasi terhadap prestasi belajar pada mata pelajaran Pemeliharaan Kelistrikan Kendaraan Ringan kelas XII program keahlian Teknik Kendaraan Ringan SMK Negeri 1 Ngawen. 
Manfaat yang diharapkan dalam penelitian antara lain memberikan ilmu pengetahuan, terutama bagi kemajuan program pendidikan pada SMK Negeri 1 Ngawen, memberikan sumbangan yang baik dalam rangka proses pembelajaran sehingga dapat meningkatkan proses pembelajaran, sebagai sumber informasi tentang pengaruh perhatian orang tua dan motivasi berprestasi terhadap prestasi belajar kelistrikan otomotif SMK Negeri 1 Ngawen.

\section{METODE PENELITIAN}

Penelitian ini termasuk penelitian Ex-post facto. Penelitian ex-post facto "yaitu penelitian tentang variabel yang kejadiannya sudah terjadi sebelum penelitian dilaksanakan" (Suharsimi Arikunto, 2006: 17). Penelitian ini merupakan penelitian ex-post facto dengan pendekatan kuantitatif. Proses penelitian kuantitatif bersifat linier, dimana langkah-langkahnya jelas dan dilakukan secara beratur mulai dari rumusan masalah, teori, hipotesis, pengumpulan data, analisis data hingga membuat kesimpulan dan saran. Penelitian ini dilakukan di SMK Negeri 1 Ngawen yang terletak di bagian utara Gunung Kidul, tepatnya di Padukuhan Jono, Desa Tancep, Kecamatan Ngawen, Kabupaten Gunung Kidul. Penelitian ini dilaksanakan pada bulan Agustus - September 2020.

Populasi dalam penelitian ini adalah semua siswa kelas XII TKR SMK N 1 Ngawen. Populasi penelitian yang berjumlah 115 siswa yang terdiri dari kelas XII OA, XII OB, XII OC, XII OD. Mengacu pada pendapat Suharsimi Arikunto (2006:131) bahwa: “Apabila subyeknya kurang dari 100 lebih baik diambil semua, akan tetapi jika subyeknya di atas 100 maka dapat diambil antara 10\%-15\% atau 20\%-25\% atau lebih". Maka penelitian ini dilaksanakan di kelas XII mata pelajaran Pemeliharaan Kelistrikan Kendaraan Ringan. Jumlah siswa kelas XII adalah 150 siswa yang terbagi dalam 4 kelas. Dari populasi tersebut diambil 20\% dari populasi sehingga jumlah sampelnya adalah 20\% x 150 siswa = 30 siswa. Maka sampel yang diambil dalam pertanian ini yaitu kelas XII OC.

Teknik yang digunakan dalam penelitian ini adalah metode angket atau kuesioner yaitu teknik pengumpulan data yang dilakukan dengan cara memberi seperangkat pertanyaan atau pernyataan tertulis kepada responden untuk dijawab. Dan metode dokumentasi untuk memperoleh data nilai ulangan harian serta nilai akhir semester (raport) siswa dalam pelajaran PKKR kelas XII SMK N 1 Ngawen. Penyusunan angket menggunakan skala Likert dengan empat pilihan skala dengan format seperti: Selalu, Sering, 
Kadang-Kadang, Tidak Pernah yang memiliki rentang skor 1-4 di mana 1 merupakan nilai terendah dan 4 merupakan nilai tertinggi untuk pernyataan positif dan sebaliknya untuk pernyataan negatif.

Tabel 1. Skor Alternatif Jawaban

\begin{tabular}{ccc}
\hline \multicolumn{3}{l}{ Pernyataan Positif } \\
\hline Skor & Alternatif Jawaban & Skor \\
\hline 4 & Selalu & 1 \\
3 & Sering & 2 \\
2 & Kadang-kadang & 3 \\
1 & Tidak pernah & 4 \\
\hline
\end{tabular}

Analisis statistik deskriptif adalah metode menganalisis yang berfungsi untuk mendeskripsikan mengenai populasi, sampel, serta obyek yang diteliti. Analisis statistik deskriptif dalam penelitian ini bertujuan untuk mengetahui gambaran masing-masing variabel penelitian disajikan dari masing-masing variabel meliputi nilai rerata (mean), nilai tengah (median), modus (mode), dan standar deviasi.

Uji Normalitas dilakukan untuk menguji data variabel bebas $(\mathrm{X})$ dan data variabel terikat (Y) pada persamaan regresi yang dihasilkan apakah berdistribusi normal atau tidak normal (Danang Sunyoto, 2007: 95). Persamaan regresi dikatakan baik jika mempunyai data variabel bebas dan variabel terikat berdistribusi mendekati normal atau normal sama sekali. Uji linieritas dimaksudkan untuk mengetahui antara variabel bebas $(\mathrm{X})$ dan variabel terikat $(\mathrm{Y})$ mempunyai hubungan yang linier atau tidak. Hubungan variabel bebas dan variabel terikat dikatakan linier apabila $F_{\text {hitung }}$ lebih kecil atau sama dengan $F_{\text {tabel. }}$

Uji multikolonieritas bertujuan untuk mengetahui di dalam model regresi ditemukan adanya korelasi yang kuat antar variabel independen atau tidak. Model regresi yang baik seharusnya tidak terjadi korelasi diantara variabel independen. Uji multikolonieritas dilakukan dengan melihat nilai Variance Inflation Factor (VIF) dan Tolerance. Ketentuan pedoman penilaian nilai VIF dan Tolerance yaitu apabila nilai VIF kurang dari 10 dan Tolerance lebih dari 0,1 maka dinyatakan tidak terjadi multikolinieritas.

Heteroskedastisitas berarti variasi variabel tidak sama untuk semua pengamatan. Uji heteroskedastisitas bertujuan untuk mengetahui di dalam sebuah model regresi terjadi kesamaan ataukah ketidaksamaan varians dari residual suatu pengamatan ke pengamatan yang lainnya. Jika residualnya mempunyai varians yang sama disebut Homoskedastisitas dan jika 
variansnya tidak sama/ berbeda disebut terjadi Heteroskedastisitas.

Untuk pengujian hipotesis yang diajukan maka dalam penelitian ini menggunakan teknik analisis regresi liner berganda dengan 2 variabel bebas dengan model persamaan regresinya adalah sebagai berikut:

$$
\mathrm{Y}=\mathrm{a}_{1} \mathrm{X}_{1}+\mathrm{a}_{2} \mathrm{X}_{2}+k
$$

Keterangan:

$\mathrm{Y}=$ Pretasi belajar PKKR

$\mathrm{X} 1, \mathrm{X} 2$ = Variabel bebas (perhatian orangtua, motivasi berprestasi) dengan taraf signifikansi 0,05 (Hadi, 2005: 2).

\section{HASIL DAN PEMBAHASAN}

\section{Hasil}

Pengujian hipotesis dalam penelitian ini dilakukan dengan menggunakan analisis regresi berganda. Penjelasan tentang hasil pengujian hipotesis dalam penelitian ini sebagai berikut.

Tabel 21. Hasil Uji Linier Berganda

\begin{tabular}{|l|l|c|c|c|c|c|}
\hline No. & Variabel & $\begin{array}{l}\text { Nilai T } \\
\text { hitung }\end{array}$ & Signifikansi & df & $\begin{array}{l}\text { Nilai F } \\
\text { Hitung }\end{array}$ & $\begin{array}{c}\text { Signifikans } \\
\text { i F }\end{array}$ \\
\hline 1. & $\begin{array}{l}\text { Perhatian } \\
\text { Orang Tua } \\
\text { (X1) }\end{array}$ & 3,459 & 0,002 & & & \\
2. & $\begin{array}{l}\text { Motivasi } \\
\text { Berprestasi } \\
\text { (X2) }\end{array}$ & 0,245 & 0,808 & 115,193 & $.000^{\mathrm{b}}$ \\
\hline
\end{tabular}

Berdasarkan data di atas menunjukkan bahwa nilai Sig. untuk variabel Perhatian Orang Tua (X1) adalah sebesar 0,002 <0,05. Maka dari itu ha diterima, artinya berdasarkan hasil analisis regresi ganda, diketahui secara parsial variabel Perhatian Orang Tua (X1) berpengaruh signifikan terhadap Prestasi Belajar (Y). Selanjutnya untuk variabel Dukungan Motivasi Berprestasi (X2), data di atas menunjukkan nilai Sig. sebesar 0,808 > 0,05. Maka dari itu ha ditolak, artinya berdasarkan hasil analisis regresi ganda, diketahui secara parsial variabel Motivasi Berprestasi (X2) tidak berpengaruh signifikan terhadap Prestasi Belajar (Y).

Hubungan antara variabel Perhatian Orang Tua (X1) dengan Prestasi Belajar (Y): Dari data di atas menunjukkan bahwa nilai t hitung untuk Perhatian Orang Tua (X1) lebih besar dari t tabel $(3,459>2,051)$. Maka dari itu hipotesis diterima, artinya berdasarkan hasil analisis regresi ganda, diketahui secara parsial variabel Perhatian Orang Tua (X1) berpengaruh signifikan terhadap Prestasi Belajar (Y). 
Hubungan antara variabel Motivasi Berprestasi (X2) dengan Prestasi Belajar (Y): Selanjutnya untuk variabel Motivasi Berprestasi (X2), data di atas menunjukkan nilai t hitung lebih kecil dari t tabel $(0,245<2,051)$. Maka dari itu hipotesis ditolak artinya berdasarkan hasil analisis regresi ganda, diketahui secara parsial variabel Motivasi Berprestasi (X2) tidak berpengaruh terhadap Prestasi Belajar (Y).

\section{Pembahasan}

Hasil penelitian ini menunjukkan bahwa semakin tinggi Perhatian Orang Tua yang dimiliki peserta didik maka akan semakin tinggi pula Prestasi Belajar PKKR, begitu pula sebaliknya semakin rendah Perhatian Orang Tua yang dimiliki peserta didik maka akan semakin menurun Prestasi Belajar PKKR. Dengan kata lain, peserta didik yang mendapatkan perhatian dari orang tuanya dengan baik khususnya dalam hal belajar maka ia akan mudah untuk melakukan kegiatan belajar dan akan mudah pula mencapai Prestasi Belajar yang baik. Dalam hal ini orang tua yang baik akan memperhatikan/memenuhi kebutuhan belajar peserta didik sehingga peserta didik akan merasa diperhatikan dan memberikan hasil terbaik untuk dirinya sendiri dan orang tua. Disamping itu hubungan orang tua dengan anak dan suasana rumah juga berpengaruh terhadap kondisi psikis anak.

Hasil tersebut memperkuat teori dari Slameto (2010: 60-63) bahwa siswa yang belajar akan menerima pengaruh dari keluarga dari bagaimana cara orang tua dalam mendidik anak di lingkungan keluarga, baiknya suatu hubungan/relasi antar anggota keluarga, suasana rumah tempat anak tinggal dan keadaan ekonomi keluarga yang mendukung dalam proses belajar anak. Orang tua dalam mendidik anak harus dilakukan dengan penuh keikhlasan dan kesadaran, hal ini dapat dilakukan contohnya dengan memberi perhatian khusus terhadap pendidikan anak, dengan cara memenuhi kebutuhan anak dalam belajar, memperhatikan anak pada saat belajar di rumah, membantu kesulitan anak, dan lain sebagainya. Begitu pula hubungan antar anggota keluarga juga berpengaruh terhadap belajar anak. Demi kelancaran belajar anak perlu diusahakan hubungan yang baik di dalam keluarga sehingga anak merasa dilimpahi kasih saying dan penuh pengertian. Faktor lain yang perlu diperhatikan yaitu suasana rumah yang nyaman dan keadaan ekonomi keluarga. Semua faktor tersebut jika terpenuhi maka akan mempermudah anak dalam hal belajar dan pencapaian prestasi belajar yang baik.

Hasil dari data penelitian menunjukkan bahwa motivasi berprestasi siswa cukup tinggi tetapi tidak berpengaruh terhadap hasil prestasi belajar dimana nilai yang didapat siswa cukup rendah. Hal ini dapat dipengaruhi oleh beberapa faktor seperti (1) siswa tidak belajar, walaupun motivasinya tinggi tetapi tidak belajar maka nilai yang didapat akan rendah, (2) tingkat kecerdasan siswa rendah, (3) siswa tidak mengikuti pembelajaran secara maksimal, (3) 


\section{Ahmad Zunaidi}

penyampaian materi oleh guru atau metode yang digunakan tidak efektif, (4) siswa menyepelekan ketika mengerjakan soal ujian, (5) dari segi soal ujian terdapat beberapa faktor seperti soal ujian sulit atau kompisisi soal banyak yang sulit, soal atau kalimat nya sulit dipahami sehingga membutuhkan waktu yang lama untuk mengerjakan, soal ujian dengan materi yang disampaikan tidak cocok, kisi-kisi ujian tidak cocok dengan soal yang diberikan. Dari uraian di atas dapat ditarik kesimpulan bahwa siswa yang memiliki motivasi berprestasi tinggi tidak selalu mendapat nilai yang tinggi karena beberapa faktor yang telah disebutkan, ini menunjukkan bahwa motivasi berprestasi tidak selalu berpengaruh terhadap hasil prestasi siswa. Hal ini berkebalikan dengan penelitian yang dilakukan Mulyatiningsih (2014) yang menyatakan bahwa motivasi belajar secara signifikan mempengaruhi prestasi belajar siswa SMK.

Motivasi berprestasi tidak berpengaruh signifikan terhadap hasil prestasi sedangkan dari hasil angket diperoleh motivasi siswa cukup tinggi, juga dapat disebabkan oleh beberapa faktor yang lebih dominan yang berpengaruh terhadap hasil prestasi yaitu faktor perhatian orang tua dan beberapa faktor yang tidak diteliti dalam penelitian ini yaitu terdapat faktor internal dan faktor eksternal. Faktor internal meliputi kondisi fisiologis dan kondisi psikologis, faktor fisiologis diantaranya (1) peserta didik yang dalam keadaan sehat jasmaninya akan berbeda belajarnya dari peserta didik dalam kondisi yang kurang sehat dan kurang gizi akan mudah lelah, mudah mengantuk, dan sulit menerima pelajaran, (2) kondisi panca indra terutama penglihatan dan pendengaran. Faktor psikologis diantaranya (1) minat, (2) bakat, (3) kemampuan belajar, (4) kecerdasan, (5) cara belajar yang efisien memungkinkan mencapai prestasi belajar yang lebih tinggi. Faktor eksternal meliputi (1) lingkungan keluarga, terutama dalam hal mendorong, memberi semangat, dan memberi teladan yang baik kepada anaknya. (2) Lingkungan pendidikan seperti sekolah merupakan faktor pendidikan yang sudah terstruktur, memiliki sistem, dan organisasi yang baik bagi penanaman nilai-nilai etika, moral, mental, spiritual, disiplin dan ilmu pengetahuan. (3) Sarana Pendidikan yang memadai, (4) keadaan ekonomi keluarga, (5) keadaan lingkungan sosial masyarakatnya.

Hasil penelitian di atas senada dengan penelitian yang dilakukan oleh Ervin Oktavianingtyas (2013) yang membuktikan bahwa variabel motivasi berpengaruh negatif terhadap prestasi belajar mahasiswa. Hal ini ditunjukkan oleh nilai koefisien regresi sebesar 0,006 tetapi secara statistik tidak berpengaruh signifikan pada taraf signifikansi 5\%, ditunjukkan oleh tingkat signifikansi sebesar 0,978 (lebih besar dari $\alpha=0,05$ ). Sehingga dapat disimpulkan bahwa variabel motivasi tidak mempengaruhi prestasi belajar mahasiswa pada taraf signifikansi 5\%. Dalam penelitian tersebut menunjukkan bahwa variabel yang berpengaruh terhadap prestasi belajar diantaranya lingkungan fisik belajar yang berpengaruh 
positif terhadap prestasi belajar mahasiswa. Hal ini ditunjukkan oleh nilai koefisien regresi sebesar 0,175 dan secara statistik berpengaruh signifikan pada taraf signifikansi 5\%, ditunjukkan oleh tingkat signifikansi sebesar 0,036 (lebih kecil dari $\alpha=0,05$ ). Variabel keadaan ekonomi keluarga secara statistik berpengaruh signifikan terhadap prestasi belajar mahasiswa. Hal ini ditunjukkan dengan hasil statistik pada taraf signifikansi 5\%, ditunjukkan oleh tingkat signifikansi sebesar 0,001 (lebih kecil dari $\alpha=0,05$ ). Variabel faktor jasmani secara statistik berpengaruh signifikan terhadap prestasi belajar mahasiswa. Hal ini ditunjukkan dengan hasil tingkat signifikansi sebesar 0,00 (lebih kecil dari $\alpha=0,05$ ).

\section{SIMPULAN}

Perhatian orang tua berpengaruh signifikan terhadap Prestasi Belajar PKKR Peserta Didik Kelas XII TKR SMK Negeri 1 Ngawen, dibuktikan dari nilai signifikansi kurang dari 0,05 yaitu sebesar 0,002 dan pada uji t (parsial) dimana nilai t hitung lebih besar dari nilai $\mathrm{t}$ tabel $(3,459<2,051)$. Sedangkan motivasi berprestasi tidak berpengaruh signifikan terhadap Prestasi Belajar PKKR Peserta Didik Kelas XII TKR SMK Negeri 1 Ngawen, dibuktikan dari nilai signifikansi lebih dari 0,05 yaitu sebesar 0,808 dan pada uji t (parsial) dimana nilai thitung lebih kecil dari nilai t tabel $(0,245<2,051)$.

Sebagai saran perbaikan, pihak sekolah sebaiknya mengadakan pertemuan rutin dengan orang tua peserta didik guna untuk mengetahui ataupun bertukar informasi mengenai kegiatan peserta didik di rumah maupun di sekolah dan apa yang akan dilakukan guna pencapaian prestasi belajar yang baik. Selain itu, Guru diharapkan untuk lebih sering memberikan motivasi belajar kepada peserta didik agar peserta didik memiliki semangat dan keinginan untuk belajar dengan baik. Guru juga perlu untuk memonitor kegiatan peserta didik bukan hanya pada saat pembelajaran saja. Selain itu guru ada baiknya dapat menjalin hubungan yang baik dengan orang tua peserta didik dan lebih sering mengkomunikasikan segala yang berhubungan dengan perkembangan peserta didik.

Peserta didik perlu menanamkan kepercayaan pada kemampuan diri sendiri sehingga mampu memotivasinya untuk melakukan segala yang terbaik, termasuk dalam hal belajar. Disamping itu peserta didik juga perlu menjalin hubungan yang harmonis dengan anggota keluarga khususnya orang tua agar peserta didik merasa nyaman dan disayangi ketika berada di lingkungan keluarga, hal tersebut dapat memicu peserta didik tidak melakukan hal-hal yang berada di luar aturan. Ada baiknya lagi jika peserta didik selalu mengkomunikasikan setiap hambatan ataupun masalah yang sedang dihadapinya sehingga orang tua dapat membantu atau memberikan perhatian lebih, hal ini khususnya dalam belajar. 


\section{DAFTAR PUSTAKA}

Afifi, M., \& Sukaswanto, S. (2020). Pengaruh kompetensi siswa dan peran serta bkk terhadap motivasi untuk bekerja di bidang otomotif siswa kelas XI jurusan teknik kendaraan ringan SMK se-Kabupaten Bantul. Jurnal Pendidikan Vokasi Otomotif, 2(2), 61-70.

Hadi, Sutrisno (2005). Metodologi Research. Yogyakarta: Yayasan Penerbitan Fakultas Psikologi UGM.

Ikhsan, Fuad. (2003). Dasar-dasar Kependidikan Komponen MKDK. Jakarta: Rineka. Cipta

Mulyaningsih, I. E. (2014). Pengaruh interaksi sosial keluarga, motivasi belajar, dan kemandirian belajar terhadap prestasi belajar. Jurnal Pendidikan dan Kebudayaan, 20(4), 441-451.

Oktavianingtyas, Ervin (2013). Studi Tentang Faktor-Faktor Yang Mempengaruhi Prestasi Belajar Mahasiswa Program Studi Pendidikan Matematika FKIP Universitas Jember. Jember: Universitas Jember.

Sjukur, S. B. (2012). Pengaruh blended learning terhadap motivasi belajar dan hasil belajar siswa di tingkat SMK. Jurnal pendidikan vokasi, 2(3).

Slameto. (2010). Belajar dan Faktor-faktor yang Mempengaruhinya. Jakarta: Rineka Cipta.

Slavin, R.E. (2009). Psikologi pendidikan teori dan praktik, edisi kedelapan, Jilid kedua (Terjemahan Marianto Samosir). Jakarta: PT Index (Buku asli diterbitkan tahun 2006).

Suharsimi A. (2006). Prosedur Penelitian suatu Pendekatan Praktek. Jakarta: PT. Rineka Cipta. 